\section{INQUA and IGCP field meeting in Denmark 1981}

https://doi.org/10.37570/bgsd-1985-34-20

On 25-30 May, 1981 a field meeting on Glacial Tectonics was held on the island of Møn, southern Denmark. It was the fifth conference of the Regional Group "Glacigenic Deposits in the Southwest Parts of the Scandinavian Icesheet". The Regional Group is a part of the INQUA Commission "On Genesis and Lithology of Quaternary Deposits". Members of the Peribaltic Group "Stratigraphy and Chronology of Weichselian (Vistulian) Deposits in the South Baltic Area", which is a part of the IGCP Project 73/ $1 / 24$ "Quaternary Glaciations in the northern Hemisphere", were also invited.

The field meeting was organized and arranged by $A$. Berthelsen and S. Sjørring, Institute of General Geology (Copenhagen) and F. Grube, Geologisches Landesamt Schleswig-Holstein (Kiel).

The field meeting was attended by 32 scientists from Austria, Canada, Denmark, the Nether-lands, Norway, Poland, Sweden, Switzerland, United Kingdom and West Germany.
The meeting comprised excursions to Ristinge Klint on Langeland (Sjørring, 1983), and on the island of Møn to Hvideklint (Aber, 1979), Madsesklint, Hjelm Nakke and Vagtbo Bakke (Berthelsen, 1979) and to the sections at Kobbelgaard and Møns Klint.

In connection with the field meeting two days of lectures and discussions took place in Store Damme, Møn. Some of the lectures held are reprinted in this volume.

Steen Sjørring

\section{References}

Aber, J. S. 1979: Kineto-stratigraphy at Hvideklint, Møn, Denmark and its regional significance. Bull. geol. Soc. Denmark 28: 81-93.

Berthelsen, A. 1979: Recumbent folds and boudinage structures formed by subglacial shear: An example of gravity tectonics. In: van der Linden, W. J. M. (ed.): Van Bemmelen and his search for harmony. Geol. en Mijnbouw 58: 252-260.

Sjørring, S. Ristinge Klint. In: Ehlers, J. (ed.): Glacial Deposits in North-West Europe, 219-226, A. A. Balkema, Rotterdam. 